\title{
WOMAN ENTREPRENEURSHIP
}

\author{
Ana Vukičević1 ${ }^{(1 D}$ \\ Anja Celić2 ${ }^{2}$
}

DOI: https://doi.org/10.31410/LIMEN.2019.135

\begin{abstract}
It is impossible to define entrepreneurship by one unique definition so there are numerous definitions that are trying to explain this complex phenomenon. Since defining woman entrepreneurship is based on gender determination it is fair to define it as entrepreneurship' woman activity. With the development of democratic society, woman enter the world of entrepreneurship in developed countries and start equal competiveness with men in entrepreneurship business after the emergence of centers for woman education where they are specialized in marketing, finance, strategic development and management sector. Democratic and developed urban areas, with developed economies, contribute to woman entrepreneurship aware of its direct impacts on positive economy development on national level. This paper is concerned with structural obstacles that include education choices, traditional view and stereotypes about woman role in society. Moreover, this paper is concerned with economy obstacles together with "soft" obstacles that include lack of access to technical, scientific and general business networks as well as lack of business training for woman.
\end{abstract}

Keywords: Entrepreneurship, Woman entrepreneurship, Innovations.

\section{INTRODUCTION}

E ntrepreneurship has been recognized as a vital part for purposive economy system. Small, medium and large entrepreneurs create more workplace; they increase the level of export and create more innovations. With the emancipations as well as gender equalizations, woman entrepreneurship is recognized as an alluring business choice. However, there are still specific obstacles specific to woman entrepreneurs. Traditional view of woman role in society still define the decision of woman education choices. Woman are perceived as less prone to risk and hard to balance personal with professional life due to the long hours that most of new innovative entrepreneurs need to be prepared for. Moreover, woman found it difficult to access finance for starting a business than a man. By eliminating these obstacles, possibilities open for increasing the potential and innovative creativity for woman. Woman leadership can facilitate in economy growth, overall economy development and help boost the workplace.

This paper is concerned with structural, economy and soft obstacles of woman entrepreneurship. The chapters in this paper are dived in four sections. After the introduction, the authors specify woman entrepreneurship in depth. The third section is concerned with the woman entrepreneurship in Europe and author provide newest statistical data on woman leadership and innovations. The forth chapter, the conclusion, summarizes the whole findings and gives propositions for further research. 


\section{WOMEN ENTREPRENEURSHIP SPECIFICATIONS}

Entrepreneurship can be defined as a possibility of creation from nothing, and with that definition, woman entrepreneur is a person that in that process needs to recognize a chance, ensures the creating and division of new value, takes a risk of money, time and reputation in order to accomplish a goal. There is no clear scientific relation that could explain the smaller amount and impact of women in business world since there are numerous reasons coming from stereotypes and values of a society, culture differences and defined opportunities in business world that are more suitable to man than to woman who are combining business obligations with motherly obligations. Woman entrepreneur do not accept a raw form of business and in economy based on profit they bring an orientation toward emotions, satisfaction and accomplishment beyond the frames defined by business itself (Batošić, 2018).

The first article on the subject of woman entrepreneurship was published by the author Eleanor Brantley Schwartz titled "Entrepreneurship, a New Female Frontier". In that article, the author comes to conclusion that woman as well as men, are led by same motives for becoming an entrepreneur: desire for accomplishment, business satisfaction and independence. Since that article has been more than 40 years, the interest of the academic and business community for this specific phenomena does not decrease. Research all around the world emphasize the fact that entrepreneurship business started by woman are important not only for gender equality but for entrepreneurship activity overall and for new jobs opening (Ivanković et al., 2016).

Some of the women entrepreneurship' characteristics can be described as following: (Marković, 2017)

- Work place opened by woman entrepreneur is more secure since woman business are smaller

- Women entrepreneurs take more of employees, quality and human relationship

- Woman entrepreneurs are more supportive in their ambitions

- They measure success not only by profit, but also with customer satisfaction, development of employee capabilities and good employee relationship

- Women are more prepared for team work, they take care more of organization' success than they personal ego

- Woman are more careful when it comes to taking loans and by taking any professional risk

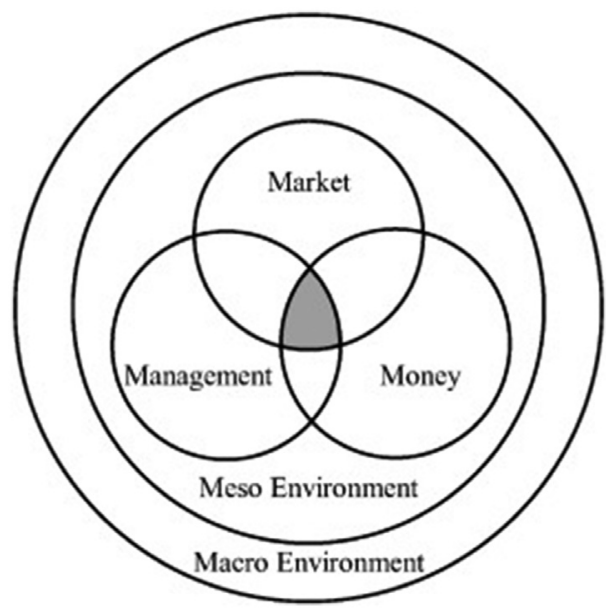

Picture 1. 5M of woman entrepreneurship

Source: Brush \& Welter, 2009., p. 13. 
The picture 1. shows Venns' diagram that clarifies the entrepreneurship activity trough 5M organization. To launch certain entrepreneurship activity, three factors are required: market, money and management, but for woman entrepreneurship, the addition of two more factors is required: motherhood and meso and macro environment. Motherhood is the factor on which all other circles overlap - it is a metaphor that represents the contexts of family and household, defines woman position and symbolizes the meaning of gender awareness (Zirdum \& Cvitanović, 2017, according to Brush at al., 2009).

Globalization, rapid technology development and changes in society together with gender equalization have direct impact on development of business creativeness and entrepreneurships' potentials for woman in managing individual businesses and management functions (Zirdum \& Cvitanović, 2017).

\section{OBSTACLES AND CHALLENGES OF WOMAN ENTREPRENEURSHIP}

The main obstacles of woman entrepreneurship can be defined as following: (Ivanković et al., 2016)

- social obstacles- lack of self-confidence, lack of vision and aspiration, lack of confidence and risk taking activities;

- education and skills - lack of proper education and skills required in entrepreneurship;

- financial obstacles - lack of initial capital and other forms of financing, insufficient information concerning possibilities of state financial aid for new entrepreneurs, inadequate bank relationship toward entrepreneurs, low offer of entrepreneurship capital for starting a business.

Moreover, woman entrepreneurs still have to overcome the difficulties connected with gender prejudice from the past together with society inequality that is still present. Main challenge in discrimination problem should be handled by legislative power since the problem is among small and medium organizations. The legislative power should be responsible for implementation of state strategies that will solve problems of gender inequality more effectively. These strategies should include different society manners, empower woman employment and self-employment and create programs that will resolve problems of woman entrepreneurship. There programs should ensure more just or equal ways of woman employment in business organizations (Gosarić, 2016., according to Kolaković, 2006).

Key problems of woman entrepreneurship are: (Batošić, 2018)

- considerable under- representation in entrepreneurship activities

- considerable under- representation in employment

- lower pays in doing the same or similar jobs as men

- considerable domination in unemployment

- considerable management under-representation

- considerable under-representation in ownership structure of an organization

- disconnection of activities for empowering woman business

- insufficient coordination and cooperation among implementation of public politics, programs and initiatives that contribute development of woman entrepreneurship

- insufficient statistical data based on gender.

When starting a business woman entrepreneurs are faced with more obstacles than men. There are still present the imposed perceptions and choices that woman have in making a decision 
about education and these choices determines their possibilities in future concerning employment. Humble choice and orientation toward certain activities and occupation leads to limitations in business activities in technological intense industry. Beside the stereotype how woman does not fit in business world, there are stereotypes about woman in science concerning the technology. Woman are marked with stereotypes concerning other possibilities since the belief is that woman are limited by time and effort needed for starting a business due to the role of mother and house keeper. Stereotypes and limitations are present not only in financing woman entrepreneurship but also in assistance and in mentoring. All of mentioned led to distorted woman' perceptions about themselves that led to lack of self-esteem and capacity for risk taking (Batošić, 2018).

It is more than interesting to look of some facts that determine the increase of woman activities in entrepreneurship. First characteristic is the fact that comes for different attitude toward genders. Second characteristic is concerned with specific entrepreneurship behavior for different countries. Moreover, strong impact on woman entrepreneurship has democratic and family structured the level of development in countries. In undeveloped countries, the increase of number of population is proportionally increased with the growth of entrepreneurship activities in both genders that is determined by growth of entrepreneurship opportunities and growth of total customer demand. Thereupon, the competition grows as the opportunities for self-employment. Besides, the discursion involves the differences in birthrate rate so in developed countries there is increase of number of non-married woman while in countries in development it decreases in woman activates in entrepreneurship is expected (Marković, 2017).

\section{WOMAN ENTREPRENEURS IN EUROPE}

In the research led by European Commission (European Commission, 2014, 15/12, Statistical Data of Women Entrepreneurs in Europe) that included 37 countries, from which included 28 countries of EU and also Albania, Macedonia, Island, Israel, Turkey, Lichtenstein, Montenegro and Serbia. The research had shown that in 2012 in Europe - 37, there was 40,6 million of active entrepreneurs; $29 \%$ of them where woman. The country with the highest rate of woman in entrepreneurship activities was Lichtenstein with $43 \%$, followed by Latvia, Luxemburg, Portugal and Croatia with 37\%. The lowest rate of woman entrepreneurship in 2012 was in Turkey (15\%).

Most of the men and woman in Europe-37 were solo entrepreneurs - $78 \%$ of woman were solo entrepreneurs, and $22 \%$ where employing others as well. In Europe - 37, woman entrepreneurs chose following activities: health care activities and social work activities $(60 \%)$, education (55\%), only $21 \%$ of woman were in manufacturing industry; $21 \%$ in communication and technology activities; and only $3 \%$ in construction.

Based on research, $59 \%$ of woman entrepreneurs were in age rate from $25-49,32 \%$ of them in age rate from 50-64, $6 \%$ older than 65 , and only $3 \%$ of them from $15-24$. In the most countries in Europe - 37 woman entrepreneurs were more educated than men entrepreneurs, and the average education level were among woman entrepreneurs in Estonia, Ireland, Belgium, Germany and Luxemburg. The lowest education level, based on this research, was in Turkey, Portugal, Romania, Albania and Croatia (Zirdum \& Cvitanović, 2017) 


\section{CONCLUSION}

With more educational options and training programs, woman entrepreneurship has become one of the leading force for economy of developed countries. However, women still face with stereotypes that slows their career success and discourage them in taking innovative actions. There is a need for most component leaders on leading positions, whether in business arena or in society, and the factor such as gender cannot be perceived as a defect or as an advantage. Society cannot prosper without joined participation of men and women in economy decision making.

The future research should involve the assessment of the active measures such as positive discrimination and measures related to gender equalization in countries that apply these measures. Moreover, it would be interesting to research how these measurements have infected women entrepreneurship.

\section{REFERENCES}

Batošić, S. (2018). Žene u poduzetništvu u Republici Hravtskoj, Sveučilište u Splitu, Split, pp. $1-48$.

Gosarić, I. (2016). Povijesni razvoj poduzetništva na primjeru ženskog poduzetništva, Sveučilište Sjever, Varaždin, pp. 1-65.

Ivanković, D., Kulenović, Ž., \& Sudarić, Ž. (2016). Žensko poduzetništvo i poduzetnička aktivnost žena $u$ Republici Hrvatskoj, International scientific conference ERAZ 2016, Beograd, pp. 576-582.

Marković, I. (2017). Žene u poduzetništvu - izazovi i ograničenja, Split, Sveučilište u Splitu, pp.1-44.

Zirdum, G. \& Cvitanović, V. (2017). Prepreke i mogućnosti razvoja ženskog poduzetništva u RH, Obrazovanje za poduztništvo, Zagreb., pp. 201-220. 